Kong. Res. J. 4(2): 151-156, 2017

ISSN 2349-2694

Kongunadu Arts and Science College, Coimbatore.

\title{
SEED DEVELOPMENT AND GERMINATION STUDIES OF TWO TRUE MANGROVE SPECIES RHIZOPHORA MUCRONATA POIR AND BRUGUIERA CYLINDRICA (L) BLUME.
}

\author{
Sekaran, $\mathbf{S}$. \\ Department of Botany, Sree Nayana College for Women, Kollam, Kerala. \\ E.mail: drsekhar72@gmail.com
}

\begin{abstract}
The present study was carried out on phenological observations and reproductive characteristics including seed development, maturation and number of days taken for produce mature propagules/seeds by the selected two important mangrove species Rhizophora mucronata. Prior Bruguiera cylindrical (L) Blume of the family Rhizophoraceae. An interesting adaptation noticed in true mangroves is that or those belonging to the family Rhizhophoraceae reproduce through a unique biological phenomenon called vivipary. In this mode of reproduction in the post fertilization the zygotes stay on the mother plant for a period 3-7 months until they mature in to seedlings or commonly called as propagules.

The physiological maturity of seeds generally determined on the basis of accumulation of higher dry weight with maximum germination. In Rhizophora macronata physiological maturity of seed determined as $14^{\text {th }}$ weeks after anthesis. The moisture content of the seed was decreased to with increase of dry weight. In Brugeiera cylindrica, the harvestable maturity can be fixed on $12^{\text {th }}$ weeks after anthesis. It was based on the maximum dry weight. $2.4 \mathrm{gm}$ with minimum fresh weight of $4.09 \mathrm{gm}$. The germination percentage of seeds was also maximum during that period.Seed maturation studies of Rhizophora mucronata indicate that the best collection time prevails from April to June and in Bruguiera cylindrica the best seed collection time prevails from May to July.
\end{abstract}

Keywords: Germination studies, mangroves, Rhizophora mucronata, Bruguiera cylindrica.

\section{INTRODUCTION}

Mangroves are halophytes occurring in saline marshy places. The word "mangroves" is considered to be a combination of the Portuguese word "mangue" and the English word "grove". Mangroves are salt tolerant forest ecosystems of the topical subtropical inter tidal regions of the word. Mangrove ecosystem is a group of numerous plants and animal interacting with each other and their surroundings. In India, Vegetation formation also termed as 'Tidal forests'. Macnae (1968) coined a new term to the mangroves i.e.; "mangal" for mangrove community and "mangrove" for individual species. Mangroves are prominent component of coastal vegetation occupying flood plains, margins of bays and tidal river in addition of shores. Uniqueness of mangrove ecosystem is that the biota is constantly under physiological stress caused by extreme conditions, mangroves have been successfully colonized by developing morphological, reproductive and physiological adaptations like pneumatophores, prop roots still roots and viviparous germination which facilities their growth in aquatic environment (Tomlinson,1986) Arunprasath and Gomathinayagam(2014) reported the phenology, reproductive biology and storage studies of five true mangrove species of Pichavaram mangrove forests of Tamil nadu. A detailed phytosociological and floristic composition of two natural mangrove vegetation including the study site Ayiramthengu of Kollam district was reported (Sekaran et al., 2015)

The scope of the present study is to analyse the various phonological and reproductive characteristics of two mangrove species in Ayiramthengu mangrove forest of Kollam district for developing a data which could be of help the forest managers in planning to regenerate the species of the mangrove forest.

\section{MATERIALS AND METHODS}

The present study was carried out on phenological observations and reproductive characteristics including seed development, maturation and number of days taken for produce mature propagules/seeds by the selected two important mangrove species Rhizophora mucronata. Prior Bruguiera cylindrical (L) Blume of the family Rhizophoraceae.

\subsection{Seed Development and Maturation studies}

The flowers of the two species were tagged separately considering the time of anthesis as the main criteria for determination of physiological 
maturity. The propagules/seeds were collected from the tagged flowers at weekly intervals to tag more number of flowers to overcome the problem of heavy flower/ fruit shedding with most care. The results were expressed as weeks $\left(1^{\text {st }}, 2^{\text {nd }}, 3^{\text {rd }}, 4^{\text {th }} \ldots .\right.$. etc $)$ the physical characters namely length, dry weight fresh weight of seed were measured during every sampling time. Physiological characters such as percent germination were studied in the above seeds periodically.

\subsection{Seed germination test}

To obtain germination percentage five replicates of 20 seeds were germinated in sandy media in a plastic germination cover placed under the tidal condition. The number of seeds germinated and the germination percentage was calculated.

\subsection{Root and Shoot length}

Ten seedlings were taken 30 da after sowing for both Rhizophora and Brugueira random from the standard germination test. The seedlings were removed from the germination cover without damaging the root and shoot, washed thoroughly to remove the adhering soil particles. The length of root and shoot was measured individually for the entire seedling selected. The shoot length was measured from collar region to the tip of the leaf and root length from collar region to the tip of the primary root and their means were expressed in centimeters. (cm).

\subsection{Vigour index}

The vigour index was calculated adopting the formula proposed by Abdul Baki and Anderson (1973) and expressed in number.

$$
\begin{aligned}
\text { Vigour index }= & \text { Germination percent } \mathrm{x} \text { (Root length } \\
& + \text { Shoot length } \mathrm{cm})
\end{aligned}
$$

\subsection{Selection of Water Media for growth of seedlings.}

To find out suitable water media for better growth of seedlings of both species. The following media were attempted in salt water and fresh water.

From this, the seedling height shoot height, basal diameter, node number, leaf number root biomass, stem biomass, leaf biomass and total biomass were recorded.

\subsection{Selection of suitable media for viability Test}

To find out suitable seed testing media for viability the following media were attempted in Sand, Sand+Humus +Soil and Clay soil
The observations on germination, Root length, Shoot length, collar diameter and number of leaves were carried out.

\section{RESULTS AND DISCUSSIONS}

\subsection{Seed development and maturation studies}

For the present study the changes in physical characters and germination of seeds/ Propagules of Rhizophora mucronata over a period of time from the date of anthesis to propagule / seed maturation at weekly intervals are given in tbale.1. The seed characters of Rhizophora mucronata is noted that the various physical characters such as are steadily increased during the process of seeds/ propagules maturation. The length, fresh weight and dry weight increased stadily in $R$. mucronata upto $12^{\text {th }}$ week after a thesis. On the other hand the moisture content of the seed was decreased during the propagules maturation i.e., ( $90 \%$ to $48.42 \%$ ). The maximum moisture content were recorded in the initial stages of seed development.

The propagules / seeds maturity of $R$. mucronata can be identify on the basis of their seed colour (greenish to brownish in colour). In $R$. Mucronata the propagule maturity attain at the period of $13^{\text {th }}$ week. The in physical characters and germination of seeds of $B$. cylindrical over a period of time from the date of anthesis to seed maturation at weekly intervals are given in table. 3 , The physical characters noted that such as fresh weight, dry weight and length were increased steadily up to $11^{\text {th }}$ week after anthesis. On the other hand, the seed moisture content was decreased rapidly throughout the study period i.e., $88.88 \%$ to $41.4 \%$. the maximum moisture content were recorded in the initial stages of seed formation.

Table 3 clearly shows that the seed formation starts at $4^{\text {th }}$ week and the physical characters like fresh weight and dry weight of seed increases and the moisture content of the propagules / seeds decreased throughout the maturation period. The seeds / propagules of B. cylindrical were started to germinate at $6^{\text {th }}$ week after anthesis. The propagules of B. cylindrical attained physiological maturity at $12^{\text {th }}$ week.

The accumulation of maximum dry weight of seeds at $12^{\text {th }}$ week indicate the physiological maturity in $R$. Murcronata and B. Cylindirca. The physiological maturity denotes the attainment of maximum dry weight. Such increase in day weight of seed during development and maturation was reported by Hocking et al, (1980) in Nuytisa, Floribunda, (Husin et al. 1981) in Hevea brassiliensis. 
Table 1. Seed development and maturation studies on Rhizophora mucronata.

\begin{tabular}{|c|c|c|c|c|c|c|c|c|c|c|c|c|c|c|c|}
\hline Week & 1 & 2 & 3 & 4 & 5 & 6 & 7 & 8 & 9 & 10 & 11 & 12 & 13 & 14 & 15 \\
\hline $\begin{array}{c}\text { Fresh } \\
\text { Weight }\end{array}$ & $\begin{array}{c}0.30 \\
( \pm 0.08)\end{array}$ & $\begin{array}{c}0.5 \\
( \pm 0.09)\end{array}$ & $\begin{array}{c}2.2 \\
( \pm 0.15)\end{array}$ & $\begin{array}{c}3.1 \\
( \pm 0.2)\end{array}$ & $\begin{array}{c}5.28 \\
( \pm 0.26)\end{array}$ & $\begin{array}{c}10.5 \\
( \pm 0.3)\end{array}$ & $\begin{array}{l}14.92 \\
( \pm 0.5)\end{array}$ & $\begin{array}{l}18.88 \\
( \pm 0.7)\end{array}$ & $\begin{array}{l}22.86 \\
( \pm 0.8)\end{array}$ & $\begin{array}{c}26.5 \\
( \pm 0.5)\end{array}$ & $\begin{array}{l}28.92 \\
( \pm 0.3)\end{array}$ & $\begin{array}{c}30.1 \\
( \pm 0.2)\end{array}$ & $\begin{array}{c}34.67 \\
( \pm 0.22)\end{array}$ & $\begin{array}{l}34.90 \\
( \pm 2.3)\end{array}$ & $\begin{array}{l}34.90 \\
( \pm 2.3)\end{array}$ \\
\hline $\begin{array}{l}\text { Dry Weight } \\
\text { (gm) }\end{array}$ & $\begin{array}{c}0.03 \\
( \pm 0.0003)\end{array}$ & $\begin{array}{c}0.07 \\
( \pm 0.0002)\end{array}$ & $\begin{array}{c}0.3 \\
( \pm 0.1)\end{array}$ & $\begin{array}{c}0.6 \\
( \pm 0.03)\end{array}$ & $\begin{array}{c}1.1 \\
( \pm 0.04)\end{array}$ & $\begin{array}{c}2.59 \\
( \pm 0.05)\end{array}$ & $\begin{array}{c}4.1 \\
( \pm 0.29)\end{array}$ & $\begin{array}{c}6.2 \\
( \pm 0.12)\end{array}$ & $\begin{array}{c}7.5 \\
( \pm 0.35)\end{array}$ & $\begin{array}{c}9.5 \\
( \pm 0.1)\end{array}$ & $\begin{array}{c}11.1 \\
( \pm 0.26)\end{array}$ & $\begin{array}{c}13.26 \\
( \pm 0.29)\end{array}$ & $\begin{array}{c}17.2 \\
( \pm 0.17)\end{array}$ & $\begin{array}{l}28.6 \\
(0)\end{array}$ & $\begin{array}{c}28.6 \\
( \pm 2.3)\end{array}$ \\
\hline Length $(\mathrm{cm})$ & $\begin{array}{c}0.32 \\
( \pm 0.1)\end{array}$ & $\begin{array}{c}0.5 \\
( \pm 0.05)\end{array}$ & $\begin{array}{c}1.22 \\
( \pm 0.07)\end{array}$ & $\begin{array}{c}2.3 \\
( \pm 0.1)\end{array}$ & $\begin{array}{c}4.0 \\
( \pm 0.23)\end{array}$ & $\begin{array}{c}6.9 \\
( \pm 0.29)\end{array}$ & $\begin{array}{c}8.5 \\
( \pm 0.23)\end{array}$ & $\begin{array}{c}11.25 \\
( \pm 0.25)\end{array}$ & $\begin{array}{l}13.33 \\
( \pm 0.2)\end{array}$ & $\begin{array}{c}14.56 \\
( \pm 0.11)\end{array}$ & $\begin{array}{c}16.70 \\
( \pm 0.23)\end{array}$ & $\begin{array}{c}17.9 \\
( \pm 0.24)\end{array}$ & $\begin{array}{c}18.36 \\
( \pm 0.25)\end{array}$ & $\begin{array}{l}19.85 \\
(0)\end{array}$ & $\begin{array}{l}19.85 \\
( \pm 2.3)\end{array}$ \\
\hline $\begin{array}{l}\text { Moisture } \\
\text { Content }\end{array}$ & $\begin{array}{c}90 \\
( \pm 2.5)\end{array}$ & $\begin{array}{c}86 \\
( \pm 3.4)\end{array}$ & $\begin{array}{c}86 \\
( \pm 3.4)\end{array}$ & $\begin{array}{c}80 \\
( \pm 2.3)\end{array}$ & $\begin{array}{c}79 \\
( \pm 2.3)\end{array}$ & $\begin{array}{c}75 \\
( \pm 1.6)\end{array}$ & $\begin{array}{c}72.5 \\
( \pm 1.3)\end{array}$ & $\begin{array}{l}67.16 \\
( \pm 2.6)\end{array}$ & $\begin{array}{l}67.10 \\
( \pm 2.1)\end{array}$ & $\begin{array}{c}64 \\
( \pm 1.3)\end{array}$ & $\begin{array}{l}61.61 \\
( \pm 1.9)\end{array}$ & $\begin{array}{c}55.9 \\
( \pm 1.1)\end{array}$ & $\begin{array}{l}50.38 \\
( \pm 0.5)\end{array}$ & $\begin{array}{l}48.42 \\
( \pm 2.3)\end{array}$ & $\begin{array}{l}48.42 \\
( \pm 2.3)\end{array}$ \\
\hline $\begin{array}{c}\text { Germination } \\
(\%)\end{array}$ & - & - & - & - & - & - & - & $\begin{array}{c}5 \\
( \pm 0.01)\end{array}$ & $\begin{array}{c}12 \\
( \pm 0.03)\end{array}$ & $\begin{array}{c}15 \\
( \pm 0.03)\end{array}$ & $\begin{array}{c}17 \\
( \pm 0.02)\end{array}$ & $\begin{array}{c}25 \\
( \pm 0.04)\end{array}$ & $\begin{array}{c}45 \\
( \pm 0.01)\end{array}$ & $\begin{array}{c}50 \\
( \pm 0.01)\end{array}$ & $\begin{array}{c}60 \\
( \pm 0.04)\end{array}$ \\
\hline
\end{tabular}

Table 2. Seed development and maturation studies on Bruguiera cylindrica.

\begin{tabular}{|c|c|c|c|c|c|c|c|c|c|c|c|c|c|c|}
\hline Week & 1 & 2 & 3 & 4 & 5 & 6 & 7 & 8 & 9 & 10 & 11 & 12 & 13 & 14 \\
\hline $\begin{array}{c}\text { Fresh } \\
\text { yeight } \\
\text { gm) }\end{array}$ & $\begin{array}{c}0.09 \\
( \pm 0.002)\end{array}$ & $\begin{array}{c}0.18 \\
( \pm 0.06)\end{array}$ & $\begin{array}{c}0.25 \\
( \pm 0.07)\end{array}$ & $\begin{array}{c}0.33 \\
( \pm 0.57)\end{array}$ & $\begin{array}{c}0.57 \\
( \pm 0.15)\end{array}$ & $\begin{array}{c}0.75 \\
( \pm 0.16)\end{array}$ & $\begin{array}{c}1.12 \\
( \pm 0.19)\end{array}$ & $\begin{array}{c}1.85 \\
( \pm 0.2)\end{array}$ & $\begin{array}{c}2.18 \\
( \pm 0.23)\end{array}$ & $\begin{array}{c}3.4 \\
( \pm 0.2)\end{array}$ & $\begin{array}{c}4.09 \\
( \pm 0.2)\end{array}$ & $\begin{array}{c}4.1 \\
( \pm 1.1)\end{array}$ & $\begin{array}{c}4.1 \\
( \pm 1.2)\end{array}$ & $\begin{array}{c}4.1 \\
( \pm 1.1)\end{array}$ \\
\hline $\begin{array}{l}\text { Dry weight } \\
\text { (gm) }\end{array}$ & $\begin{array}{c}0.01 \\
( \pm 0.001)\end{array}$ & $\begin{array}{c}0.03 \\
( \pm 0.06)\end{array}$ & $\begin{array}{c}0.05 \\
( \pm 0.003)\end{array}$ & $\begin{array}{c}0.08 \\
( \pm 0.03)\end{array}$ & $\begin{array}{c}0.15 \\
( \pm 0.01)\end{array}$ & $\begin{array}{c}0.24 \\
( \pm 0.03)\end{array}$ & $\begin{array}{c}0.43 \\
( \pm 0.05)\end{array}$ & $\begin{array}{c}0.95 \\
( \pm 0.1)\end{array}$ & $\begin{array}{c}1.10 \\
( \pm 0.19)\end{array}$ & $\begin{array}{c}1.9 \\
( \pm 0.19)\end{array}$ & $\begin{array}{c}2.4 \\
( \pm 0.05)\end{array}$ & $\begin{array}{c}2.4 \\
( \pm 0.03)\end{array}$ & $\begin{array}{c}2.4 \\
( \pm 0.04)\end{array}$ & $\begin{array}{c}2.4 \\
( \pm 0.05)\end{array}$ \\
\hline $\begin{array}{l}\text { Length } \\
\text { (cm) }\end{array}$ & $\begin{array}{c}0.2 \\
( \pm 0.09)\end{array}$ & $\begin{array}{c}0.5 \\
( \pm 0.1)\end{array}$ & $\begin{array}{c}0.8 \\
( \pm 0.08)\end{array}$ & $\begin{array}{c}1.2 \\
( \pm 0.1)\end{array}$ & $\begin{array}{c}2.35 \\
( \pm 4.67)\end{array}$ & $\begin{array}{c}4.67 \\
( \pm 0.23)\end{array}$ & $\begin{array}{c}6.30 \\
( \pm 0.24)\end{array}$ & $\begin{array}{c}7.92 \\
( \pm 0.3)\end{array}$ & $\begin{array}{c}10.68 \\
( \pm 1.32)\end{array}$ & $\begin{array}{l}12.32 \\
( \pm 0.2)\end{array}$ & $\begin{array}{c}13.2 \\
( \pm 0.3)\end{array}$ & $\begin{array}{c}13.2 \\
( \pm 1.2)\end{array}$ & $\begin{array}{c}13.2 \\
( \pm 0.2)\end{array}$ & $\begin{array}{c}13.2 \\
( \pm 0.3)\end{array}$ \\
\hline $\begin{array}{c}\text { Moisture } \\
\text { content }(\%)\end{array}$ & $\begin{array}{l}88.88 \\
( \pm 2.2)\end{array}$ & $\begin{array}{l}83.33 \\
( \pm 2.6)\end{array}$ & $\begin{array}{c}80 \\
( \pm 2.5)\end{array}$ & $\begin{array}{l}75.75 \\
( \pm 2.5)\end{array}$ & $\begin{array}{l}73.36 \\
( \pm 1.7)\end{array}$ & $\begin{array}{c}68 \\
( \pm 2.0)\end{array}$ & $\begin{array}{l}61.60 \\
( \pm 1.9)\end{array}$ & $\begin{array}{c}51 \\
( \pm 2.3)\end{array}$ & $\begin{array}{l}49.54 \\
( \pm 2.1)\end{array}$ & $\begin{array}{l}44.11 \\
( \pm 2.1)\end{array}$ & $\begin{array}{l}41.32 \\
( \pm 1.1)\end{array}$ & $\begin{array}{c}41.4 \\
( \pm 0.5)\end{array}$ & $\begin{array}{l}41.4 \\
( \pm 1.1)\end{array}$ & $\begin{array}{c}41.4 \\
( \pm 1.2)\end{array}$ \\
\hline $\begin{array}{c}\text { Germination } \\
(\%)\end{array}$ & - & - & - & - & - & - & - & $\begin{array}{c}5 \\
( \pm 0.01)\end{array}$ & $\begin{array}{c}12 \\
( \pm 0.03)\end{array}$ & $\begin{array}{c}15 \\
( \pm 0.03)\end{array}$ & $\begin{array}{c}17 \\
( \pm 0.02)\end{array}$ & $\begin{array}{c}25 \\
( \pm 0.04)\end{array}$ & $\begin{array}{c}45 \\
( \pm 0.01)\end{array}$ & $\begin{array}{c}50 \\
( \pm 0.01)\end{array}$ \\
\hline
\end{tabular}

\pm : Standard Deviation 
Table 3. Effect of different seed testing media on germination percentage, shoot length and root length and Vigour index of Rhizophora mucronata and Bruguiera Cylindrica

\begin{tabular}{|c|c|c|c|c|c|c|c|c|}
\hline \multicolumn{5}{|c|}{ R.mucronata } & \multicolumn{4}{|c|}{ B.cylindrica } \\
\hline Coad tactina madis & $\begin{array}{c}\text { Germination } \\
\%\end{array}$ & $\begin{array}{l}\text { Shoot length } \\
\text { (cm) }\end{array}$ & $\begin{array}{l}\text { Root length } \\
\text { (cm) }\end{array}$ & $\begin{array}{l}\text { Vigour } \\
\text { Index }\end{array}$ & $\begin{array}{c}\text { Germination } \\
\%\end{array}$ & $\begin{array}{c}\text { Shoot } \\
\text { length }(\mathrm{cm})\end{array}$ & $\begin{array}{l}\text { Root length } \\
\text { (cm) }\end{array}$ & $\begin{array}{l}\text { Vigour } \\
\text { Index }\end{array}$ \\
\hline Sand & 44 & 18.3 & 10.3 & 1258 & 40 & 7.9 & 12.8 & 828 \\
\hline Sand + humus + Red soil & 61 & 23.9 & 12.9 & 2245 & 56 & 10.1 & 14.5 & 1378 \\
\hline Clay soil & 88 & 32.6 & 16.6 & 5210 & 75 & 12.3 & 18.9 & 2340 \\
\hline
\end{tabular}

Table 4. Effect of water condition on growth parameters and biomass of mangrove seedling

\begin{tabular}{|c|c|c|c|c|c|c|c|c|c|c|c|}
\hline \multirow[t]{2}{*}{ Species } & \multirow[t]{2}{*}{ Period } & \multicolumn{5}{|c|}{ Tidal water dipping seedlings } & \multicolumn{5}{|c|}{ Land keeping seedlings } \\
\hline & & $\begin{array}{r}\text { Shoot } \\
\text { Length }\end{array}$ & $\begin{array}{c}\text { Root } \\
\text { length }\end{array}$ & $\begin{array}{c}\text { Collar } \\
\text { Diameter }\end{array}$ & $\begin{array}{l}\text { Number } \\
\text { of leaves }\end{array}$ & $\begin{array}{c}\text { Biomass } \\
\text { of } \\
\text { seedling }\end{array}$ & $\begin{array}{l}\text { Shoot } \\
\text { length }\end{array}$ & $\begin{array}{c}\text { Root } \\
\text { length }\end{array}$ & $\begin{array}{c}\text { Collar } \\
\text { diameter }\end{array}$ & $\begin{array}{c}\text { Number } \\
\text { of } \\
\text { leaves }\end{array}$ & $\begin{array}{c}\text { Biomass } \\
\text { Of } \\
\text { seedling }\end{array}$ \\
\hline & 30 days & 20.5 & 7.9 & 4.5 & 2 & 23.5 & 22 & 8 & 3.9 & 2 & 22 \\
\hline \multirow{3}{*}{ R.mucronata } & 60 days & 29 & 10.5 & 6.8 & 6 & 28.9 & 28 & 10 & 6 & 4 & 26 \\
\hline & 90 days & 32.8 & 15.1 & 9.3 & 8 & 35.1 & 31 & 12.6 & 8 & 6 & 30 \\
\hline & 30 days & 14.5 & 6.5 & 3.3 & 2 & 6.6 & 12.2 & 6.1 & 3.4 & 2 & 5.3 \\
\hline \multirow[t]{2}{*}{ B.cylindrica } & 60 days & 19.1 & 8.6 & 5.7 & 4 & 9.1 & 16.1 & 7.3 & 5.2 & 4 & 7 \\
\hline & 90 days & 22.8 & 11.4 & 7.6 & 6 & 13.6 & 20 & 10.1 & 7 & 6 & 11.3 \\
\hline
\end{tabular}

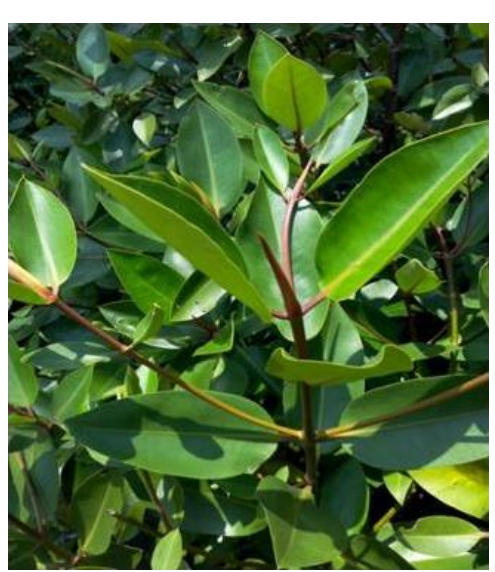

Rhizophora mucronata

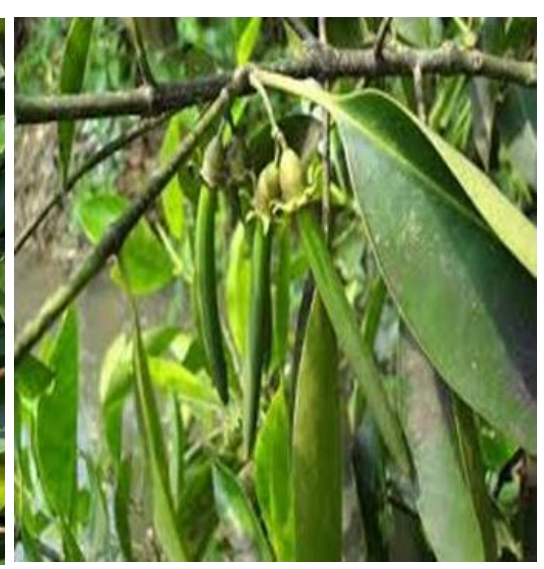

Bruguiera cylindrica

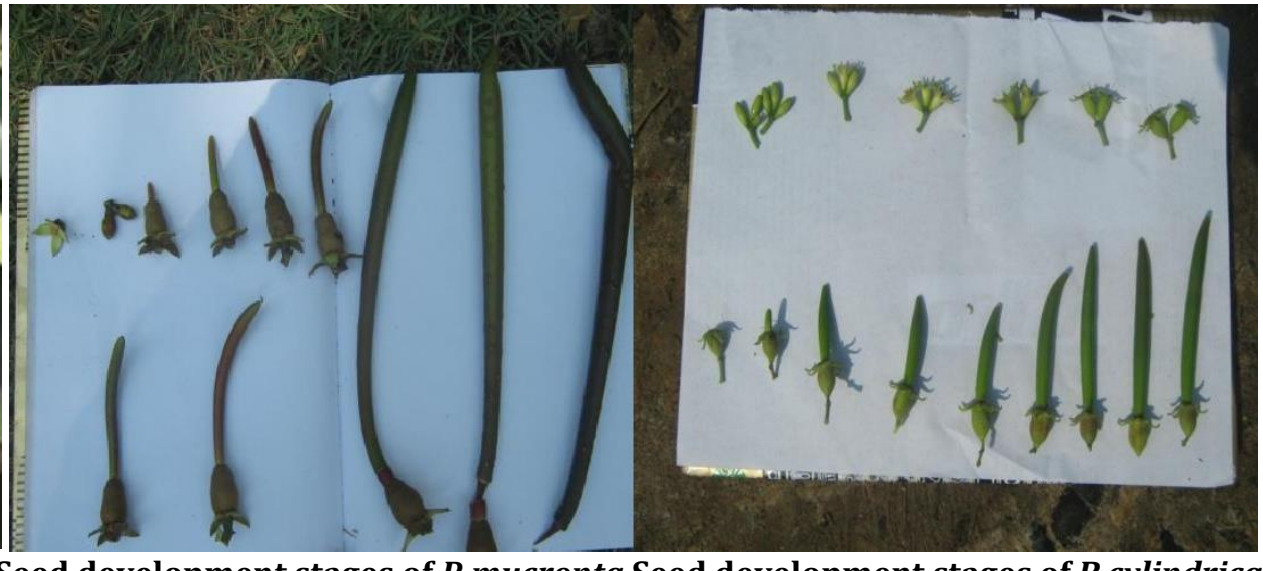

Seed development stages of R.mucronta Seed development stages of B.cylindrica 


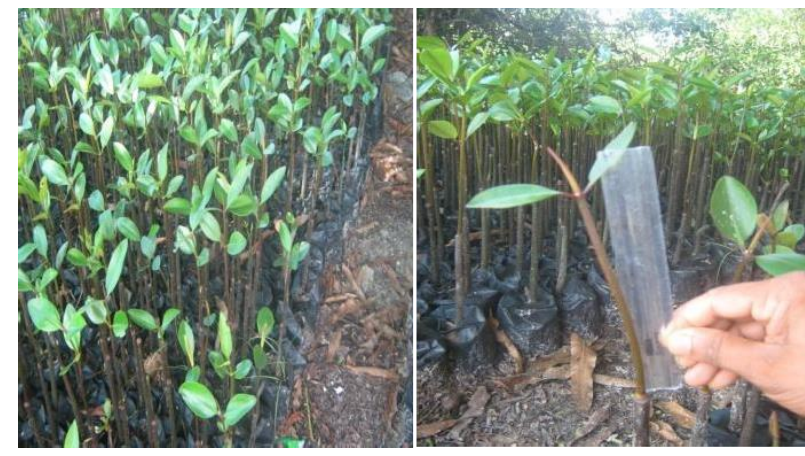

Growth Rate in Nursery Stages of Rhizophora mucronata

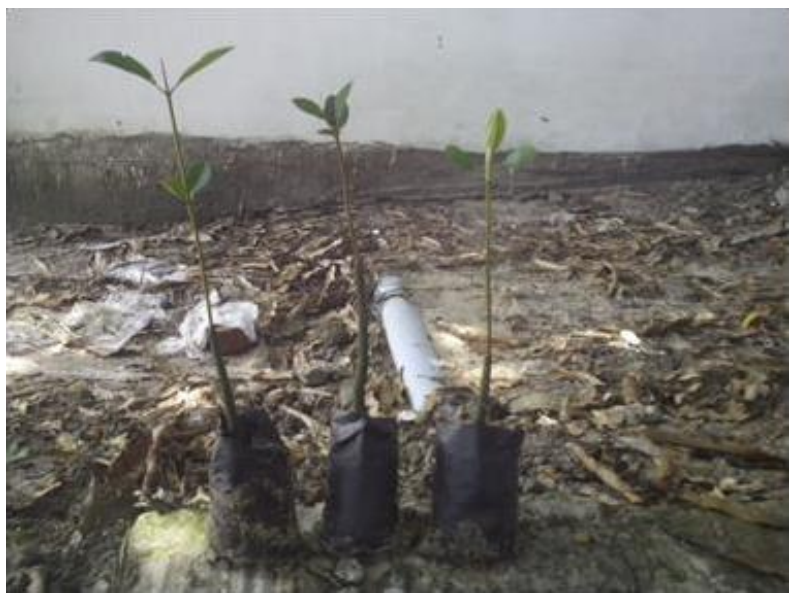

Growth Rate In Nursery Stages of Bruguiera cylindrical

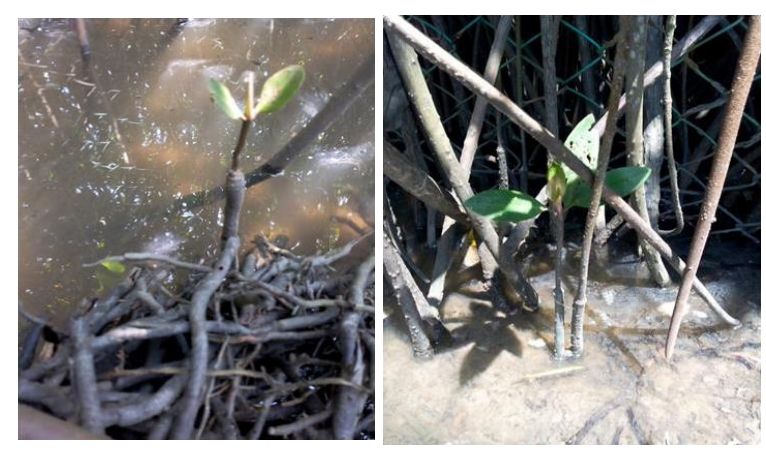

Effect of growth of Rhizophora mucronata and Bruguiera cylindrical in tidal and land keeping seedlings

The increase in dry weight of seed might be due to decrease in the moisture content coupled with increased accumulation of food reserve material. however, the change in seed dry weight were not related to change in seed dry weight were not related to change in seed quality of marrow (Demir and Ellis,1993).

\subsection{Effect of seed testing medium on germination,} shoot length and root length
The seeds of Rhizophora mucronata were sown on different testing media such as sandy soil, sand + humus + redsoil, clay soil, conditions for the observation on germination, root-length, shoot length were recorded (Table.3). The freshly collected seeds of R. mucronata shows maximum germiability in clay soil ie., $88 \%$ and les germination in sandy soil i.e., $43 \%$.

The maximum root length, shoot length and germination percentage of seeds were recorded in muddly soil present in that area. The average shoot length and root length of seeds are $33.6 \mathrm{~cm}$ and $16.6 \mathrm{~cm}$, and it is decreased in other mediums.

The seeds of Bruguiera cylindrical were also sown in three different testing media such as muddy soil, sandy soil and sand soil + humus + Red soil, Conditions for observation on germination, root length and shoot length of seeds were recorded (Table.5). The freshly collected seeds of B. Cylindrica shows maximum germiability in muddy soil, i.e. $75 \%$ and less germination in sandy soil. The maximum root length, shoot length and germination percentage of seeds were recorded in muddy soil. The average root and shoot length of seeds are $12.3 \mathrm{~cm}$ and $18.9 \mathrm{~cm}$.

\subsection{Effect of growth in tidal and land keeping seedlings of R. mucronata and B.cylindrica}

The seeds of R.mucronata and B.cylindrica are placed in tidal condition and in land, the effect of seeds of both species are different in these conditions. To observe the seedling growth of R.mucronata and B.cylindrica after 30 days, 60 days and 90 days, the tidal water dipping seedlings show $\mathrm{s}$ higher growth than land keeping seedlings. The characters of seedlings-shoot length, root length, collar diameter, number of leaves and dry weight of seedlings is higher in tidal water dipping seedlings and lesser in land keeping seedlings. (Table.4)

\section{REFERENCES}

Abdul-Baki, A.A. and J.D. Anderson. (1973). Vigour determination in soybean seed by multiple criteria. Crop Sci., 13: 630-632.

Anuprasath A and M. Gomathinayagam (2014). Reproductive biological studies in True Mangrove Species of Pichavaram Mangrove Forest, India- A Comparative account. National seminar on Green Living for Sustainable Development., $15-17^{\text {th }}$ October.Government Brennen College, Thalassery. Abs pp 73.

Demir, I. and R.H. Ellis. (1993). Changes in potential seed longevity and seedling growth during seed 
development and maturation in marrow. Seed sci.and Res., 3:247-257.

Hocking, P.J., T. Kuo and T.S.Patil.(1980). Mineral nutrition of developing fruits of the Western Australian Christmas tree, Nuytsia Floribunda (Labill). R.Br. Ex-Fenzl. Aust. J.Bot., 28:1-17.

Husin, S., M.Bin, H.F Chin and V.L Hur. (1981). Fruit and seed development in Havea (clone RRIB 600) in Malaysia. JK.Rubber Res. Inst. Malaysia, 29:101-113.
Macnae, w. (1968). A general account of the fauna and flora of mangrove swamps and forests in the Indo -West Pacific region. Adv. Mar. Biol. 6:73-270.

Sekaran.S, S.Nisha Raj, S.Arun and S. Paulsamy (2015). Floristic constitution and certain ecological characters of two selected natural mangrove vegetation in Kollam district, Kerala. J. Research in Biology 5(5)1763-1768.

Tomlinson, P.B 1986. The Botany of Mangroves. The Cambridge university press, Cambridge. 